\title{
Pravo roditelja da utječu na obrazovanje djece s obzirom na vlastita uvjerenja
}

\author{
Asea Gašparič*
}

\begin{abstract}
Sažetak
Imaju li roditelji pravo utjecati na obrazovanje vlastitoga djeteta svojim autoritetom primarnoga odgajatelja ili ne, pitanje je podijeljenih odgovora koje je izazvalo burne polemike u društvu. Ususret 30. obljetnici donošenja Konvencije o pravima djeteta napisan je ovaj rad koji za cilj ima prikazati važnost vrijednosnoga sustava obitelji u kontekstu odgoja djeteta. U radu se kroz pravne propise najprije iznosi pravna utemeljenost takve ovlasti roditelja, nakon čega se prikazuje doseg relevantnih odredaba. Na kraju, autorica se osvrće na hrvatsku stvarnost u pogledu toga područja izlažući zaključna razmišljanja s obzirom na legitimnosti prava roditelja.
\end{abstract}

Ključne riječi: pravo na obrazovanje; vjerski odgoj; roditeljska uvjerenja; vjeronauk

\section{Uvod}

Odgoj i obrazovanje u demokratskom su društvu dobili status ljudskih prava. S današnje perspektive više se ne dovodi u pitanje važnost tih prava, ali ostaje za razmišljati kako svladati nove izazove i doprinijeti njihovu boljemu ostvarivanju. Obiteljskopravna teorija prepoznaje pravo djeteta na odgoj i obrazovanje kao jedno od izvornih dječjih prava kojima se stvara temelj za daljnji napredak djetetove osobnosti (Hrabar, 1994, 89).

Za dijete odgoj znači usvajanje kulturnih, socijalnih i moralnih vrijednosti od malih nogu i pomoć pri ulasku u svijet odraslih. »U zemljama s razvijenom demokracijom roditeljima se priznaje status glavnih odgajatelja djece te se postavljaju granice utjecaja države u pogledu njezina odgojnog, političkog $i$ vjerskog utjecaja na najmlađe« (Maleš et al., 2003, 33). U odnosu na obrazovanje, suvremeni svijet postavlja zahtjev za pluralizmom. »Obrazovanje se određuje kao proces kojim se stvaraju uvjeti, norme i principi kao i potrebite kompetencije koje će dijalog među

* Pravni fakultet Sveučilišta u Zagrebu. Adresa: Trg Republike Hrvatske 14, 10000 Zagreb, Hrvatska. ORCID: 0000-0003-2725-488X. E-adresa: gasparic.asea@gmail.com 
različitim kulturama učiniti mogućim «(Gerin, 2017, 1). Obrazovanje započinje od rođenja, traje kroz školsko doba, ali se nastavlja i tijekom cijeloga života. Pravo na obrazovanje nalazimo među izvornim pravima djeteta (Alinčić et al., 2007, 229) upravo zato što je ono preduvjet veće kvalitete života u odrasloj dobi, a njegovo ostvarivanje bez roditelja i ostalih društvenih aktera nije moguće. Zbog snažne isprepletenosti i korelacije tih prava, neizbježan je utjecaj roditelja, uz odgoj, i na obrazovanje vlastitoga djeteta. Obiteljski je zakon kroz institut roditeljske skrbi uobličio pravni titulus roditelja za odgoj i obrazovanje vlastite djece koji predviđa odgovornost roditelja za ostvarivanje djetetova prava (čl. 91), a istovremeno »osigurava pravni legitimitet i pravnu osnova prema trećima da skrbe o svojem djetetu « (Alinčić et al., 2007, 219). Dakako uz roditelje, koji za dijete predstavljaju prvu odgojnu sredinu, od velike su važnosti i škole koje obavljaju »djelatnost osnovnog odgoja i obrazovanja « (Zakon o odgoju i obrazovanju u osnovnoj i srednjoj školi).

Dječja su prava, zbog svoje iznimnosti, vrlo često u samom fokusu zbivanja, pa je tako pravo djeteta na odgoj i obrazovanje posljednjih mjeseci središte različitih polemika. Imaju li roditelji pravo sudjelovati u obrazovanju svoje djece ili nemaju neiscrpna je tema novinara, ali i mnogih drugih kritičara. U kontekstu roditeljeva prava na sudjelovanje u odgoju, ali i obrazovanju vlastitoga djeteta neizbježno je dotaknuti se pitanja nastave vjeronauka. Okruženi člancima različitih novinara čitamo: »Država u školama ne smije nametati nikakvu ideologiju« (Turčin i Lilek, 2018), »vjera se podučava u vjerskim zajednicama«(HINA, 2018), a pravo roditelja na odgoj i obrazovanje vlastite djece zanemareno je i potisnuto. Uzevši u obzir nerazumijevanje (namjerno ili stvarno?), ostaje se zapitati imaju li takve otrovne strjelice kojima se napada na roditeljska prava u pogledu odgoja i obrazovanja vlastite djece za cilj potaknuti ukidanje vjeronauka, odgajanje djece prepustiti u potpunosti školama ili nešto treće?

Kroz ovaj rad pokušavamo dati odgovor na pitanje gdje je granica roditeljeva sudjelovanja u obrazovanju vlastitoga djeteta? Je li pravo roditelja tražiti obrazovanje djeteta u skladu s vlastitim uvjerenjima kršenje prava djeteta na obrazovanje ili legitimno roditeljsko pravo? Je li provođenje nastave vjeronauka u školama pravno utemeljeno? Preteže li pravo roditelja na odgoj i obrazovanje nad pravom školskoga sustava? Hoće li ignoriranje roditeljskoga prava te izbacivanje vjeronauka iz škola vratiti društvo na nekadašnji socijalistički sustav u kojem je djecu odgajala država, bez uvažavanja roditeljevih moralnih vrijednosti?

\section{Legitimnost roditeljskoga prava na odgoj djeteta u skladu s vlastitim uvjerenjima}

Zbog heterogenosti društva, nužno je prepoznati različite ljudske potrebe i, u skladu s pluralnošću, pojedincima omogućiti njihovo ostvarivanje propisano različitim nacionalnim i međunarodnim propisima. 


\subsection{Nacionalni propisi}

Roditeljsko pravo na odgoj vlastite djece prepoznaje i Ustav Republike Hrvatske, koji govori o važnost sudjelovanja roditelja u odgoju vlastite djece te $\mathrm{u}$ komplementarni odnos stavlja njihovo pravo i slobodu da samostalno odlučuju o odgoju djece i pravo djeteta da mu roditelji osiguraju potpun i skladan razvoj njegove osobnosti. Iz takve stilizacije vidljivo je da roditelji imaju temeljno pravo i na, inter alia, vjerski odgoj djece. Iako je riječ o posebnim, dječjim pravima, važno je prepoznati da se "prava djeteta ne shvaćaju kao suprotnosti pravima odraslih niti su alternativa ukidanju prava roditelja, već se shvaćaju kao dio ljudskih prava « (Maleš et al., 2003, 34). Omogućavanje roditeljima da sudjeluju u obrazovanju svoje djece kroz oblikovanje plana i programa nastave ustavna je obveza države, a osobito se odnosi na sadržaje povezane s različitim uvjerenjima koja se ne zasnivaju na znanstveno utemeljenim činjenicama.

Zakon o odgoju i obrazovanju u osnovnoj i srednjoj školi u čl. 4 kao jedan od ciljeva odgoja propisuje: »odgoj i obrazovanje učenika u skladu s općim kulturnim i civilizacijskim vrijednostima, ljudskim pravima i pravima djece, osposobljavanje učenika za življenje u multikulturalnom svijetu, za poštivanje različitosti i toleranciju te za aktivno i odgovorno sudjelovanje u demokratskom razvoju društva« U suradnji s roditeljima, škole imaju zadatak djecu odgojiti u odgovorne i tolerantne ljude s osjećajem poštovanja prema drugima. S obzirom na društvene, političke i gospodarske promjene važno je prilagoditi odgojno-obrazovne ciljeve te ih upraviti na cjelokupni razvoj učenika. Promicanje odgojnih vrijednosti treba biti, u skladu s pravom roditelja da samostalno odlučuju o odgoju djece, kulturalno odgovarajuće za sve učenike kako bi se ostvarilo kvalitetno obrazovanje, bez diskriminacije. Zadaća je obrazovnoga sustava da osigura poučavanje objektivno, kritički i vrijednosno neutralno, kao što je to u više presuda presudio Europski sud za ljudska prava. Od učenika se ne smije očekivati prilagođavanje ideologiji ili religiji, osobito protivno željama njihovih roditelja, a budući da je vjeronauk ustrojen kao školski predmet koji ima izborni status, djeci je, zajedno s roditeljima, prepušteno odlučiti hoće li njihovo dijete sudjelovati na nastavi takvoga sadržaja.

Kad govorimo o obrazovanju, »ono kao proces $i$ sadržaj mora biti oslonjen na roditeljski odgoj jer u protivnome kod djeteta stvara konfuziju i niječe odgovornost roditelja za skladan razvoj djetetove osobnosti« (Hrabar, 2018, 322). Roditelji via facti imaju najviši stupanj odgovornosti i utjecaja u pogledu odgoja, ali i obrazovanja vlastite djece. U tom smislu, odgojno-obrazovne institucije imat će tek supsidijarnu ulogu. Spajanjem i ispreplitanjem odgoja i obrazovanja kompletno oblikujemo osobu, pri čemu »vjeronaučna poduka ne može izostati iz potpunog projekta « (Grocholewski, 2010, 183). U isticanju važnih uporišta za opravdanost vjeronauka u školi, osim Ustava, Ugovora Republike Hrvatske sa Svetom Stolicom i političke volje, »valja više isticati važnost religije (kršćanstva) za život pojedinaca i društva, njezina doprinosa u oblikovanju života pojedinaca, hrvatske kulture i hrvatskoga društva« (Mandarić, 2012, 902). 


\subsection{Medunarodni propisi}

Neotuđivo je pravo roditelja, kao primarnih odgajatelja, djecu podizati u skladu s vrijednostima za koje smatraju da su dobre i ispravne. Navedeno pravo jamči ponajprije Opća deklaracija o ljudskim pravima, koja u članku 26. među ostalim propisuje i roditeljevo pravo "prvenstva u izboru vrste obrazovanja za svoju djecu«. Prvi u odgoju su roditelji, a institucije školskoga sustava na suradan će način sudjelovati vodeći računa o vrijednosnim aspektima koje roditelji smatraju važnima.

Konvencija o pravima djeteta u čl. 18. izrijekom navodi da su »roditelji odgovorni prije svih za odgoj $i$ razvoj djeteta «. Po prirodi stvari, zbog nesamostalnosti djece, roditelji su za svoje dijete odgovorni, pri čemu im država pomaže. Dapače, vlade država dužne su roditeljima pružiti potporu kako bi mogli svojoj djeci osigurati što kvalitetniji odgoj, a isto sugerira i Odbor za prava djeteta, čija je uloga pratiti stanje djece u državi te davati smjernice kroz izvješća. Uz potrebnu suradnju roditelja i države, Konvencija o pravima djeteta kaže da obrazovanje mora biti usmjereno k cjelovitomu razvoju osobnosti djeteta, uz pravo djeteta na slobodu misli, savjesti i vjeroispovijedi, obuhvaćajući člankom 18 dva koncepta: roditeljsku odgovornost (responsibilities) i razvojne sposobnosti djeteta (evolving capacities). Dakako, u pogledu odgoja djeteta u skladu s vjerskim i moralnim sustavom vrijednosti roditeljsko pravo nije apsolutno, pa je stoga nužno poštovati najprije djetetovo pravo na slobodu misli, savjesti i vjeroispovijedi (čl. 14) te pravo na izražavanje mišljenja (čl. 12). »Sloboda vjeroispovijedi sasvim sigurno nije shvaćena kao isključivo unutarnja sloboda, što proizlazi iz odredbe stavka 3. istog članka u kojoj se spominje sloboda očitovanja religije ili uvjerenja « (Hlača i Popović, 2009, 281). U današnje je vrijeme već ustaljeno poimanje djeteta kao pravnoga subjekta, zbog čega mu se mora omogućiti aktivno sudjelovanje u svim pitanjima koja utječu na njegov život uvažavajući slobodu izražavanja mišljenja propisanu čl. 12. Nedvojbeno, djeca zbog krhkosti nisu u mogućnosti svoja prava samostalno ostvarivati, ipak o tom pitanju odluku na kraju donose roditelji, pri čemu roditeljsko pravo na odgoj djece treba tumačiti u svjetlu roditeljske odgovornosti, a ne nadmoći. Svakako, roditeljsko je pravo relativizirano djetetovom dobrobiti, pri čemu su odgoj i obrazovanje "podređeni djetetovu pravu na obrazovanje kako ga podrazumijeva Konvencija o pravima djeteta i njegovu pravu na slobodu savjesti, vjerskog i drugog uvjerenja « (Hrabar, 2018, 328).

Roditeljska je dužnost da djetetu osiguraju, u skladu s njegovim razvojnim sposobnostima, odgovarajuće usmjeravanje i vođenje u ostvarivanju prava. S tim u vezi, zahtjeva se da roditelji, uz pomoć države, osiguraju vjerski odgoj za svoju djecu u skladu s vlastitim uvjerenjima, ali u skladu s djetetovim pravom na slobodu vjeroispovijedi vodeći se kriterijem dobrobiti djeteta. Valja imati na umu da dijete kao još nerazvijena i neoblikovana osoba nije u stanju donositi razborite odluke, pa će stoga roditeljsko pravo na primarni odgoj biti pretežnije, uvažavajući djetetov najbolji interes. Slično navedenomu, čl. 14 pred države postavlja zahtjev da poštuju prava i dužnosti roditelja pri usmjeravanju i ostvarivanju djetetovih prava. Iz takve formulacije nedvosmisleno je vidljiva sloboda roditelja. 
Za područje odgoja i obrazovanja od velike je važnosti Rezolucija Vijeća Europe 1904, koja daje smjernice u području slobode pri izboru obrazovanja te izrijekom navodi da je obrazovanje »nužan preduvjet da se svakomu pojedincu omogući da u potpunosti razvije i izvrši svoju ulogu u društvu. « Sintagmom »u potpunosti razvije i izvrši svoju ulogu« Vijeće Europe upozorava da obrazovanje ne podrazumijeva samo kruto prenošenje znanja i informacija, nego i, kao što gore spomenuta rezolucija ističe, »vrijednosti koje njeguju zaštitu i promicanje temeljnih prava, demokratskoga građanstva i socijalne kohezije. «(Rezolucija Vijeća Europe 1904)

Navedeno pravo na slobodu izbora u obrazovanju treba tumačiti restriktivno. Ono obuhvaća obvezu države da poštuje pravo roditelja da zahtijevaju obrazovanje i poučavanje djeteta u skladu s njihovim vjerskim i filozofskim uvjerenjima, ako su temeljeni na vrijednostima Vijeća Europe. Hoće li zamišljene vrijednosti iznjedriti nove temelje u pogledu odgoja i obrazovanja te hoće li oni biti usklađeni s hrvatskom tradicijom, ostaje tek vidjeti.

Povelja o temeljnim pravima Europske unije (2010/C 83/02) govori o pravu roditelja da vlastitoj djeci osiguraju obrazovanje Kao recentniji dokument, spomenuta Povelja o temeljnim pravima temeljena je na zajedničkim vrijednostima država članica Europske unije i čl. 2 Prvoga protokola uz Europsku konvenciju za zaštitu ljudskih prava i temeljnih sloboda. (dalje u tekstu: Prvi protokol) U čl. 14 govori o slobodi roditelja da svojoj djeci osiguraju obrazovanje i poučavanje u skladu sa svojim vjerskim i filozofskim uvjerenjima, poštujući nacionalne zakone koji uređuju ostvarivanje takve slobode i prava. Štoviše, proširujući doseg već uvriježenoga pravila iz Prvoga protokola, Povelja o temeljnim pravima Europske unije dodaje i obvezu poštovanja roditeljskih pedagoških uvjerenja pri poučavanju djece.

\section{Doseg članka 2 Prvoga protokola kroz praksu Europskoga suda za ljudska prava}

Škola postaje žarište sukoba države i pojedinca, sekularista i vjernika. Doista, »obrazovna arena predstavlja kritičku i napetu vezu između religije i zakona, pri čemu se postavljaju pitanja treba li religija biti podučavana u školi do toga smiju li vjerski simboli biti vidljivo istaknuti« (Fokas, 2018, 1). Međutim, danas u vrijeme različitosti potrebno je preispitati važnost religije u obrazovanju prateći međunarodne pravne standarde.

Zbog heterogenosti današnjega društva važno je poštovanje prava roditelja na odgoj i obrazovanje vlastitoga djeteta. Da je tomu tako svjedoči i Prvi protokol u čl. 2: »Nikomu neće biti uskraćeno pravo na obrazovanje. U obavljanju svojih funkcija povezanih sodgojem i poučavanjem država će poštovati pravo roditelja da osiguraju odgoj i poučavanje u skladu sa svojim vjerskim i filozofskim uvjerenjima «

Te dvije rečenice moraju biti tumačene ne samo u međuodnosu, nego i u kontekstu Konvencije za zaštitu ljudskih prava i temeljnih sloboda, pri čemu Eu- 
ropski sud za ljudska prava osobito ističe pravo svih, uključujući djecu i roditelje, na poštovanje privatnoga i obiteljskoga života te pravo na mišljenje, savjest i vjeroispovijed i slobodu primanja i širenja informacije. Pravo je djeteta biti naučavano objektivnim istinama, a u slučaju kad postoji dvojba u pogledu znanstvene utemeljenosti činjenica nastavnoga gradiva roditelji imaju pravo reći hoće li ili neće njihovo dijete takvu nastavu pohađati. Stoga, u pogledu znanstveno utemeljenih činjenica i školskih predmeta koji se na njima temelje, djeci ne može i ne smije biti uskraćena edukacija, a u odnosu na poučavanje o moralnim i vjerskim vrijednostima roditelji će imati utjecaja.

Iako je prvom rečenicom čl. 2 Prvoga protokola svakomu zajamčeno pravo na obrazovanje, ono dakako nije apsolutno. Najprije jer kao takvo traži regulaciju od strane države, pri čemu je uređenje školskoga kurikula prepušteno diskrecijskoj ocjeni države. S druge strane, država je obvezna poštovati roditeljska uvjerenja, ali to ne znači da ona mora omogućiti obrazovanje kako to roditelji požele.

Međutim, Europski sud za ljudska prava ipak je respektirao roditeljsko pravo da svojim autoritetom odgajatelja utječu na školski sustav zahtijevajući da se njihova djeca izuzmu s nastave koja se odnosi na sve predmete, a ne samo vjersku poduku, ako se djecu podučava vrijednostima s kojima se oni ne slažu (v. presude ESLJP Jimenez Alonso and Jimenez Merino v. Spain; Dojan and Others v. Germany).

Pravo roditelja na odgoj i obrazovanje djece u skladu s vlastitim uvjerenjima i diskusija o problematici nastave vjeronauka doista su teme koje okupiraju javnost već duže vrijeme. »Danas nije prijeporno da u cjelini tog odgoja, što zbog odgoja sama, što zbog prava roditelja na vjerski odgoj djece u školi, vjeronauk zauzima svoje prirodno i nezaobilazno mjesto u školi« (Pavlović, 2001, 339). Roditeljsko je demokratsko pravo tražiti obrazovanje, ali i odgoj, vlastita djeteta u skladu sa svojim uvjerenjima jer je nezamislivo da dijete kod kuće uči jedno, a da je u školi podučavano istoj stvari iz drugačije perspektive.

Organizacija plana i programa nacionalnoga kurikula u nadležnosti je države. Iako roditeljima i dalje ostaju prava da savjetuju svoju djecu, ili ih poučavaju vrijednostima do kojih drže neovisno o školskom planu i programu, ponekad je doista potrebno, ako se žele poštovati roditeljska uvjerenja, djecu izuzeti s pojedinih predmeta. U suprotnom je riječ o kršenju čl. 2 Prvoga protokola. Na državi je odgovornost da osigura, neutralno i nepristrano, ostvarivanje obrazovanja i uvažavanje prava, posebno između suprotstavljenih skupina. Nadalje, Europski sud za ljudska prava u presudi Kjeldsen, Busk Madsen and Pedersen v. Denmark ponavlja da čl. 2 Prvoga protokola nalaže državi da poštuje uvjerenja roditelja tijekom cijeloga državnoga obrazovnog programa, pri čemu Sud smatra da je, iako su prava manjina ponekad podređena pravu većine, važno postići balans koji demokratsko društvo zahtijeva.

\section{Važnost utjecaja roditelja na odgoj i obrazovanje vlastitoga djeteta}

Valja imati na umu da roditelji imaju najveću odgovornost za odgoj vlastite djece, a škole i ostali aktivni sudionici djetetova života imaju supsidijarnu ulogu. 
Država ne smije i ne može odgajati djecu protivno volji njihovih roditelja. »Kako je odgoj uvijek bio, a na poseban je način to očito danas, društveni izazov visokoga ranga, ne može država ignorirati obitelj, isto kao što obitelj ne može ignorirati usluge, odnosno mogućnosti odgoja koje nudi država preko školskih institucija (Pažin, 2010, 191). Preambula Konvencije o pravima djeteta podupire obitelj kao »temeljnu društvenu skupinu za razvoj i dobrobit svih njezinih članova, osobito djece«, a čl. 5 zajedno s čl. 18 uređuje okvir za odnos između djeteta, njegovih roditelja i obitelji, te države.

Roditelji imaju primarnu odgovornost osigurati najbolji interes djeteta shvaćajući ga kao najviše načelo koje obvezuje sve subjekte, pa tako i roditelje. Njihova je odgovornost ograničena pravima i dobrobiti djeteta, a za naše potrebe ta se ograničenja osobito tiču prava djeteta na slobodu misli, savjesti i vjere (čl. 14. Konvencije o pravima djeteta). Njihova je uloga povlaštena, kako u odnosu na prava tako i u odnosu na obveze. Mnogi su iznosili kritike pristrano i neobjektivno tumačeći da uplitanje roditelja u obrazovni sustav i zahtijevanje da školstvo poštuje njihova vjerska i filozofska uvjerenja nije u skladu s osnovnim pravom djeteta na obrazovanje. Međutim tvrdnju koja je propisana Konvencijom o pravima djeteta u čl. 18 »Roditelji ili zakonski skrbnici snose najveću odgovornost za odgoj i razvoj djeteta « treba shvaćati ponajprije u odnosu na državu, a manje dijete. Stoga odgojno-obrazovni programi i ciljevi ne smiju biti u suprotnosti s obiteljskim temeljnim vrijednostima. Uloga roditelja stavlja naglasak na odgovornosti, a ne prava.

\section{Prihvatljivost religijskoga obrazovanja u hrvatskom društvu}

Iako je vjeronaučna nastava u službi ostvarivanja integralnoga obrazovanja, ipak ostaje pitanje tretira li se vjeronauk jednako kao i ostali školski predmeti, ili bi vjerska pitanja previđena za nastavu vjeronauka u modernom svijetu svaki pojedinac trebao ostaviti za sebe u svoja četiri zida.

Doista čudi benevolentnost države prema manjinskim skupinama, najčešće aktivističkim udrugama, koje gorljivo zagovaraju izbacivanje vjerske poduke iz sustava školstva, iako se takvim modelom nikako ne bi uvažavalo djetetovo pravo da bude odgajano sukladno vjerovanjima svojih roditelja. »Takvo poimanje u zapadnoeuropskim zemljama, između ostalih šire i političke snage i stranke, socijalisti i liberali, često s pozicija vlasti. Katolička Crkva nije sklona prihvatiti takav ideološki pristup školskom vjeronauku. Ona smatra da je predavanje vjeronauka u školama 'pozitivni izraz vjerske slobode u demokratskoj državi', da učenici katolici imaju pravo pohađati katolički vjeronauk u školama: radi se o jednom od osnovnih ljudskih prava i prava obitelji« (Glas Koncila, 2001, 213). Ono što možemo primijetiti je da upravo taj isti manjinski dio hrvatskoga društva negira činjenicu da još uvijek većina učenika pohađa vjeronauk u školama. Iako je riječ o neospornom i važnom ljudskom pravu, zbog mnogo sukobljenih tumačenja, doista se teško oteti dojmu da je srž samoga problema duboka rascijepljenost društva, pri čemu se čini da manjina pokušava nadglasati većinu. 
»Već cijelo desetljeće vjeronauk je u Hrvatskoj sastavni dio odgojno-obrazovnog sustava, no još uvijek je mnogo konfuzije glede njegova identiteta i doprinosa u ostvarivanju odgojnih ciljeva (Mandarić, 2001, 5). Međutim, zbog dominacije katoličanstva neizostavan je Ugovor sa Svetom Stolicom o suradnji na području odgoja i kulture kojim se Hrvatska, u svjetlu načela o vjerskoj slobodi obvezala poštovati »temeljno pravo roditelja na vjerski odgoj djece « te odlučila »u sklopu školskog plana i programa jamčiti nastavu katoličkog vjeronauka kao obveznog predmeta za sve one koji ga izaberu « (čl. 1). Njegova je uloga, uz ostale općeobrazovne predmete, doprinijeti sveobuhvatnomu odgoju djeteta vodeći se moralnim vrijednostima. U današnje vrijeme društvo prepoznaje različite kulture, običaje i vjere, a slijedom toga obrazovanje se gradi na novim idejama i ciljevima odgoja koji zagovaraju pluralizam mišljenja. Upravo s toga stajališta opravdano je izvođenje nastave vjeronauka u javnim školama. »Vjeronaučni su sadržaji povezani gotovo sa svim područjima znanja te time vjeronauk za učenike postaje važan interpretacijski ključ za razumijevanje ne samo religijskih sadržaja nego i razumijevanje cjelokupne stvarnosti « (Razum, 2014, 567), pri čemu doprinosi sveobuhvatnomu razvoju osobe, a ne samo pukomu stjecanju teorijskih znanja za budući život.

Pravobraniteljica za djecu istaknula je sporno uključivanje vjerskih sadržaja u programe koji su namijenjeni svim učenicima (Pirnat Dragičević, 2019, 63). Pritužbe su podnosili roditelji na postupanja vrtića i škola koje su uključivale djecu u vjerske sadržaje poput blagoslova škola ili molitve. Takvim načinom, zaključuje, djeci se uskraćuje sloboda izbora zajamčena Konvencijom o pravima djeteta, a roditeljima zajamčeno pravo sudjelovanja u odgoju. U tom je pogledu pravobraniteljica upozorila na odredbe Konvencije o pravima djeteta naglašavajući važnost »uvažavanja vjerskih osjećaja pripadnika svih vjeroispovijesti, jednako kao i drugih svjetonazora i da se nitko ne osjeća isključenim ili manje vrijednim « (Pirnat Dragičević, 2019, 62). Valja istaknuti kako su tradicija i kultura kao dio hrvatskoga identiteta neizostavne u odgoju i obrazovanju, a osobito je zanimljiva činjenica da u Republici Hrvatskoj isti oni koji u očima javnosti poštuju kršćanske blagdane i običaje simultano zahtijevaju izbacivanje školskih manifestacija povezanih s vjerom poput Dana kruha ili ukrašavanja pisanica ili izvođenja božićnih jaslica. Međutim, unatoč aktualnoj klimi u društvu, rješenje nikako ne vidimo u ukidanju obilježavanja pojedinih običaja. Ono što se čini primjerenim, a gdje prepoznajemo propust škole u odnosu na djecu koja nisu odgajana u duhu vjere ili pripadaju drugoj vjeroispovijesti, jest predvidjeti neobveznu nazočnost. U skladu s načelom tolerancije, škole djeci trebaju osigurati uvažavanje njihove vjere, odnosno ateističkih uvjerenja te ih prilikom takvih događanja ne obvezivati na sudjelovanje.

Zadatak je države uvažavati multikulturalnost te poštovati prava djece i uvjerenja roditelja. »Aktualni procesi u odgojno-obrazovnim reformama često ukazuju da se odgoj i obrazovanje i njegove relevantne institucije udaljavaju od njegove temeljne zadaće, a to je osposobljavanje za razumijevanje životne stvarnosti te pomoć u cjelovitom razvoju osobnosti, koje pretpostavlja moralno-duhovnu dimenziju. A upravo se kroz proces aktualne sekularizacije događa marginaliziranje religije $i$ op- 
ćenito svetoga « (Mandarić, 2015, 339). Pravo na obrazovanje nije samo pitanje jednakoga pristupa obrazovnim prilikama, nego i aktivnoga sudjelovanja djece u životu, toliko bitnoga za njihov osobni razvoj, promicanje međusobnoga razumijevanja, tolerancije i prijateljstva. Najvažnije je imati na umu kako djeca nisu objekti, nego subjekti obrazovanja, kojima treba biti omogućeno da zajedno sa svojim roditeljima budu uključeni u donošenje odluka koje se njih tiču.

\section{Zaključak}

Zadatak roditelja prenošenje je i upoznavanje vlastite djece s vrijednosnim okvirom koji i sami prihvaćaju. Kako bi osigurali odgoj temeljen na takvim vrijednostima, na državi je da, u skladu s ustavnom obvezom, omogući roditeljima sudjelovanje u obrazovanju djeteta i odabiru nastavnih sadržaja. Odgoj i obrazovanje osposobljuju djecu za budućnost. Zbog toga je važno štititi nedvojbeno pravo roditelja da svoju djecu odgajaju prema vlastitim vjerskim i filozofskim uvjerenjima, pri čemu je neizbježna pomoć drugih relevantnih sudionika djetetova života, poput ostalih članova obitelji i društva, vrtića, škola, Crkve. Cjeloviti odgoj i obrazovanje nužno uključuje i njegovu duhovnu, odnosno religioznu dimenziju. Međutim, danas se o vjerskoj pripadnosti nerijetko govori s negativnim prizvukom, kao da to neizmjerno važno pitanje čovjekova identiteta treba zanemariti ne bi li diskriminirali ili ugrožavali neistomišljenike.

Budući da pitanje religijskoga obrazovanja, a dakako i odgoja, u javnom školstvu predstavlja posebno osjetljivu temu, najprije je nužno njegovo uređenje predvidjeti kvalitetnim zakonima u čije je donošenje važno uključiti sve zainteresirane aktere. Pravo je roditelja na odgoj i obrazovanje vlastite djece ugrađeno u nacionalne i međunarodne propise. Roditelji od društva trebaju dobiti pomoć i podršku kako bi svoju odgajateljsku zadaću što bolje izvršili, poštujući njihovo neotuđivo i prirodno pravo da svoju djecu uče vrijednostima do kojih drže. To se posebice odnosi na izazove koje suvremeno društvo u pogledu odgoja stavlja pred društvo.

Škole kao institucije imaju zadatak pomoći roditeljima pri odgoju njihove djece. To dakako znači slijediti roditeljski odgoj, vjerovanja i uvjerenje, a ono što bi prilikom neuvažavanja roditeljskih uvjerenja mogao biti problem nedosljedan je odgoj u vrijednosnom smislu u školama i kod kuće. Kako bi se izbjegla moguća konfuzija, nezaobilazno je poštovanje roditeljskih želja i uvjerenja. Takav pristup u kojem se želje roditelja poštuju roditeljima olakšava odgoj, pri čemu osobito vjeronauk u školama zbog svoje vrijednosne težine iznimno utječe na oblikovanje osobnosti djeteta. U odnosu prema vjerskom odgoju u školama »postoje i roditelji praktični vjernici koji žele da vjeronauk u školi pomogne njihovoj djeci i mladima u izgradnji osobnosti i čvrstoga vjerskog stava, koji znaju svrhu i ciljeve katoličkoga vjeronauka u školi, koji su glasnici njegove iznimno značajne uloge u cjelokupnom odgoju i obrazovanju djece i mladih « (Šimunović, 2010, 339). Njihovo je legitimno pravo takav oblik poduke zahtijevati oslanjajući se, uz mnoge propise, osobito na čl. 2 Prvoga protokola. Primjenom relevantnih odredaba, Europski sud za 
ljudska prava u više je predmeta odlučivao o vjerskom odgoju u javnim školama, te je izrijekom više istaknuo važnost poštivanja roditeljskih prava, pri čemu je obveza države da stvori model obrazovanja koji bi sprječavao indoktrinaciju, koja bi se mogla smatrati nepoštovanjem vjerskih i filozofskih uvjerenja roditelja, te obrazovao djecu po načelu vjerske slobode. Međutim, kako se stvari nerijetko izvrću, može se čuti obrnuta teza, kako upravo religija, misleći pritom ponajviše na Katoličku crkvu, provodi indoktrinaciju u školama. Takve napade smatramo neutemeljenim zbog prethodno iznesenih argumenata kojima se jasno potvrđuje izbornost vjerskoga odgoja za dijete.

Pozivanje na sekularnost i s nerazumijevanjem citiranje Ustavom propisanih normi decidirano pokazuje nerazumijevanje sukusa polemike. Takve je primjedbe otklonio Europski sud za ljudska prava, koji je dopustio isključivu autonomiju države hoće li uvesti vjersku nastavu u javnim školama i, ako hoće, na koji će ju način organizirati, pri čemu je jedino ograničenje zabrana indoktrinacije. Budući da Katolička crkva ima važnu ulogu u hrvatskoj povijesti, razumljivo je kako je većinski vjerski odgoj u školama predviđen za djecu kršćane, a ponajviše katolike. Takvo uređenje ne čudi s obzirom na činjenicu da se u Republici Hrvatskoj 92\% stanovnika izjašnjavaju kao kršćani, a njih preko $87 \%$ pripada katoličanstvu (Državni zavod za statistiku, 2013). Dakako, to ne umanjuje mogućnost roditelja da za svoje dijete zahtijevaju poduku u skladu s vlastitim vjerovanjima, ako su različita od kršćanskih vrijednosti. Roditeljsko pravo da djecu odgajaju u skladu s vlastitim sustavom vrijednosti samo je pojačanje za kvalitetnije obrazovanje. Posebno valja imati na umu da su roditelji oni koji snose najveću odgovornost za odgoj vlastite djece, a u tom smislu zadaća je odgojno-obrazovnih institucija, ponajprije škole, da ih podupiru, osobito u vrijednosnim pitanjima. Nezamislivo je pojmiti državnu moć da otuđi djecu i odgaja ih protivno volji roditelja, neuvažavajući stečevinu europske demokracije, koja se temelji na pravu izbora.

Na kraju, zabranimo li roditeljima djelovati u obrazovnom životu vlastite djece, ostaje se zapitati je li stvarno moguće provoditi Ustavom propisano pravo roditelja da samostalno odgajaju dijete sukladno svojim vrijednostima, ako je ono istovremeno u školama poučavano suprotnomu.

\section{Literatura}

Alinčić, Mira; Hrabar, Dubravka; Jakovac-Lozić, Dijana; Korać Graovac, Aleksandra (2007). Obiteljsko pravo. Zagreb: Narodne novine.

Državni zavod za statistiku (2013). Popis 2011: Jer zemlju čine ljudi. Zagreb: Državni zavod za statistiku Republike Hrvatske.

Fokas, Effie (2018). Religion and education in the shadow of the European Court of Human Rights. Politics and Religion, 12, 1-15.

Gerin, Filip (2017). Integracija nacionalnih manjina u osnovnoškolski odgoj $i$ obrazovanje u Republici Hrvatskoj - primjer Roma u Sisku (Diplomski rad). Prirodoslovno-matematički fakultet Sveučilišta u Zagrebu.

Grocholewski, Zenon (2010). Korisna uloga školskog vjeronauka: Pozdravni govor na XIV. susretu Europskog foruma za školski vjeronauk na temu "Odgoj u službi civili- 
zacije ljubavi”, Rim, 7. travnja 2010. Kateheza: časopis za vjeronauk u školi, katehezu $i$ pastoral mladih, 32(3), 181-187.

Glas koncila, Zagreb (2001). Ugovori između Svete Stolice i Republike Hrvatske, Hrvatska biskupska konferencija

HINA (2018). Ministrica na udaru: HNS poručio da se vjera podučava u vjerskim zajednicama. "Hoćemo li djecu učiti da je zemlja ravna ploča?" Novi list, 6. travnja 2018. URL: http://novilist.hr/novilist_public/layout/set/print/Vijesti/Hrvatska/MINISTRICA-NA-UDARU-HNS-porucio-da-se-vjera-poducava-u-vjerskim-zajednicama.-Hocemo-li-djecu-uciti-da-je-zemlja-ravna-ploca (11.11.2019.)

Hlača, Nenad; Popović, Petar (2009). Pravo djeteta na slobodu savjesti i vjeroispovijedi. Bogoslovska smotra, 79(2), 275-303.

Hrabar, Dubravka (1994). Dijete — pravni subjekt u obitelji. Zagreb: Pravni fakultet Sveučilišta u Zagrebu.

Hrabar, Dubravka (2018). Odjek roditeljskih vjerskih i filozofskih uvjerenja na odgoj i obrazovanje djece u hrvatskoj legislativi. Zbornik Pravnog fakulteta u Zagrebu, 68(3-4), 319-336.

Maleš, Dubravka; Milanović, Mirjana; Stričević, Ivanka (2003). Živjeti i učiti prava: Odgoj za ljudska prava u sustavu predškolskog odgoja. Zagreb: Filozofski fakultet Sveučilišta u Zagrebu.

Mandarić, Valentina (2001). Odgojna, kulturna i evangelizacijska dimenzija vjeronauka u školi. Kateheza: časopis za vjeronauk u školi, katehezu i pastoral mladih, 23(1), 5-16.

Mandarić, Valentina (2012). Konfesionalni vjeronauk pred izazovima dekristijanizirajuće Europe. Bogoslovska smotra, 82(4), 819-915.

Mandarić, Valentina (2015). Suvremene tendencije u društvu — izazov za vjeronauk u školi. Diacovensia, 23(3), 337-354.

Pavlović, Ante (2001). Religiozan odgoj u sustavu javnih škola. Kateheza: časopis za vjeronauk u školi, katehezu i pastoral mladih, 23(4), 339-352.

Pažin, Ivica (2010). Vjeronauk u školi — mjesto dijaloga Crkve i društva. Riječki teološki časopis, 35(1), 189-220.

Pirnat Dragičević, Helenca (2019). Izvješće o radu pravobraniteljice za djecu 2018. Zagreb: Pravobranitelj za djecu Republika Hrvatska.

Razum, Ružica (2017). Vjeronauk u školi u službi dijaloga i pomirenja. Bogoslovska smotra, 87(3), 553-575.

Šimunović, Josip (2010). Vjeronauk u školi između roditeljskih očekivanja, društvenih ciljeva, potreba mladih i crkvenog služenja čovjeku. Crkva u svijetu, 45(4), 391-516.

Turčin, Kristina; Lilek, Mirela (2018). Stručna javnost protiv zakona: "Država ne smije u školama nametati nikakvu ideologiju!” Jutarnji list, 7. travnja 2018. URL: https:// www.jutarnji.hr/vijesti/hrvatska/strucna-javnost-protiv-zakona-drzava-ne-smije-uskolama-nametati-nikakvu-ideologiju/7214055/ (11.11.2019.)

\section{Pravni propisi:}

Ustav Republike Hrvatske, Narodne novine, 56/90, 165/97, 8/98, 113/00, 124/00, 28/01, 55/01, 76/10, 85/10, 05/14

Konvencija o pravima djeteta, Narodne novine, Međunarodni ugovori, 12/93

Opća deklaracija o ljudskim pravima, Narodne novine, Međunarodni ugovori, 12/2009

Povelja o temeljnim pravima Europske Unije, Službeni list Europske Unije C202/393

Prvi protokol uz Europsku konvenciju za zaštitu ljudskih prava i temeljnih sloboda, Narodne novine, Međunarodni ugovori, 18/97 
Rezolucija Vijeća Europe 1904, Narodne novine 89/2010

Zakon o odgoju i obrazovanju u osnovnoj i srednjoj školi, Narodne novine, 87/08, 86/09, 92/10, 105/10, 90/11, 5/12, 16/12, 86/12, 126/12, 94/13, 152/14, 7/17, 68/18

Presude Europskog suda za ljudska prava:

Jimenez Alonso and Jimenez Merino v. Spain (https://hudoc.echr.coe.int/eng\#š\%22item id\%22:[\%22001-5973\%22]\})

Dojan and Others v. Germany (https://hudoc.echr.coe.int/eng\#š\%22item id\%22:[\%22001-106382\%22]\})

Kjeldsen, Busk Madsen and Pedersen v. Denmark (https://hudoc.echr.coe.int/eng\#š\%22 itemid\%22:[\%22001-57509\%22]\})

The Freedom of Parents to Decide on Their Children's Upbringing in Regard to Religious Education

Asea Gašparić

\section{Summary}

The issue of religious education for children in schools has elicited heated debates in Croatian society. Public opinion is divided on whether the authority of a primary educator allows for the parents to claim the right to influence the way the education of their children is conducted. As we approach the 30th anniversary of the adoption of the Convention on the Rights of the Child, this paper aims to demonstrate the importance of a family's value system in the context of child-rearing. It does so in the following way: firstly, national and international directives serve as a means to indicate the legal basis of parents' having a voice in the matter. Secondly, the practice of the European Court of Human Rights demonstrates the scope of relevant regulations, focusing mainly on Article 2, Protocol No.1 of the European Convention of Human Rights. Finally, the author depicts circumstances in Croatia in regard to education and provides closing opinions on the necessity of education, especially religious, in schools and the legal basis of the parents' right to subject their children to religious education in accordance with their value system.

Key word: right to education; religious education; parents' beliefs

* Asea Gašparić, Faculty of Law, University of Zagreb, Address: Trg Republike Hrvatske 14, 10 000 Zagreb, Croatia. E-mail: gasparic.asea@gmail.com 